\title{
sciendo
}

\author{
ALEKSANDRA JAREMEK ${ }^{1}$, JUSTYNA PIECHNIK ${ }^{1}$, ALEKSANDRA JUSZCZAK ${ }^{1}$, \\ BARBARA NIERADKO-IWANICKA²
}

\section{The attitude of students of Lublin universities to vaccination in the COVID-19 period}

\begin{abstract}
Introduction. Vaccines are one of the greatest achievements of modern medicine. The compulsory vaccination schedule was introduced in Poland in the 1950s. Vaccinations are sometimes followed by adverse effects (ARV). The most common symptoms of ARV are swelling, redness and soreness at the injection site, usually lasting up to 24 hours after vaccination.

Aim. The aim of our study was to check the attitude of students of Lublin universities to vaccination in the COVID-19 period.

Material and methods. In December 2020 we conducted an anonymous and voluntary survey. It was uploaded and shared on the Google online survey platform. A total of 75 students participated in the study.

Results. The respondents were 56 women and 19 men. Out of them 30 (40\%) were from Medical University of Lublin (MUL), 15 (20\%) from University of Life Sciences (ULS), 21 from University of Marie Sklodowska-Curie (UMCS) (28\%) and 9 from Lublin University of Technology (LUT) (LP) (12\%). Their mean age was 22 years \pm 1.1 (SD). More than half of the respondents were not interested in compulsory vaccinations before the COVID-19 pandemic. Only about 35\% (18 persons) of people expressed a positive opinion about vaccines and they were students of MUL. Although $80 \%$ of respondents answered that the anti COVID-19 vaccine is necessary, but $81 \%$ thought that Poles had not enough knowledge about the vaccine. Students themselves most often obtained information about vaccines and ARVs from Internet.

Conclusion. Students of MUL were the most enthusiastic about mandatory vaccinations and anti COVID-19 immunization. Poles need more reliable information about vaccine to change their attitude towards it.
\end{abstract}

Keywords: vaccination; COVID-19 pandemic; adverse reaction to vaccination.

DOI: $10.2478 /$ pjph-2021-0004

\section{INTRODUCTION}

The first vaccine was developed in the 18th century. Doctor Edward Jenner in 1796 carried out an experiment involving the vaccination of an eight-year-old boy with the cowpox virus. The boy developed a mild form of the disease and became immune to smallpox as well. In the 19th century, this method spread almost all over Europe, and soon also around the world [1]. Odo Bujwid was the precursor of Polish vaccinologists [2]. The compulsory vaccination schedule was introduced in Poland in the 1950s [3,4].Vaccines are one of the great achievements of modern medicine. However, they are sometimes followed by adverse effects.

In 2019, an animal coronavirus (named SARS-CoV-2) acquired the ability to carry and spread in humans, and in China appeared the first outbreaks of the disease induced by COVID-19. The World Health Organisation (WHO) on March 11, 2020 announced a pandemic, the epicentre of which quickly began to move from Asia to Europe and the North America. In Poland, at the beginning of December 2020 the total number of cases identified COVID-19 has passed one million. COVID-19 can be life-threatening, especially among people at high risk. The epidemic is very dangerous as due to a high percentage of infected patients who demand hospitalization which very quickly leads to overload of the healthcare system. Unfortunately, after going through the COVID-19 infection, it is not clear whether one develops permanent immunity for this disease. Therefore, we are facing the straight choosing to vaccinate against COVID-19 or taking part in the hard to predict illness-related complications. The scale of the COVID-19 pandemic shows that only global action, including mass vaccinations, will allow to interrupt the virus circulation. Vaccinations are the safest way of acquiring immunity against COVID-19. The vaccines against SARS-CoV-2 are mRNA ones. Research on this technology has been running for about 20 years. The mRNA vaccines are considered very safe due to: lack of possibility to modify the patient's DNA, no possibility of causing infection, rapid degradation of mRNA from the vaccine to harmless ingredients and very low dose of mRNA being necessary to produce the therapeutic effect. High antibody titers against SARS-CoV-2 were obtained in 7 days after the shot in clinical trial. After the second dose $90 \%$ of subjects developed immunity. It is worth pointing out that vaccines against COVID-19, like other vaccines available on the European pharmaceutical market, pass through rigorous procedures related to clinical trials and release to trading [5].

\footnotetext{
${ }^{1}$ Students' Scientific Association at the Chair and Department of Hygiene, Medical University of Lublin, Poland

${ }^{2}$ Chair and Department of Hygiene, Medical University of Lublin, Poland
} 
Some people are afraid of vaccines in general because of possible side effects. Adverse reactions to vaccination (ARVs) are possible after every type of vaccination. ARV is a medical condition that occurs up to 4 weeks after vaccination. The only exception are reactions after vaccination against tuberculosis - in these cases the time criterion is significantly extended. In terms of frequency, ARVs can be divided into very frequent, frequent, moderately frequent, rare and very rare reactions $[6,7]$.

Disturbing symptoms include fever, usually accompanied by a red throat, cough and sometimes diarrhea. One of the worrying symptoms is also a rash, difficulty breathing. In children, we may notice increased crying for no apparent reason. The most common symptoms of ARV are swelling, redness and soreness at the injection site, usually lasting up to 24 hours after vaccination $[8,9]$. According to the Regulation of the Minister of Health of December 21, 2010 on AVRs and the criteria for their diagnosis, serious AVR is when:

1. requires hospitalization;

2. leads to a permanent loss of physical or mental ability;

3. ends in subject's death.

A moderate ARV is a reaction, which is characterized by a high intensity of symptoms in the form of significant limb swelling, severe redness, high fever, but:

1. does not usually require hospitalization;

2. does not lead to permanent damage to health;

3 . is not life threatening.

The mild AVR is characterized by the following:

1. local limb edema;

2. strong local redness;

3. fever [10].

The subject of vaccination has become very popular recently. This is due to the increase in anti-vaccination movements, in particular the situation related to the coronavirus induced disease (COVID-19) pandemic. Even at the beginning of the year 2020, everyone was looking with hope at scientists trying to find a vaccine and a cure for COVID-19. Now when the first batch of vaccines has been manufactured, the society has very divided views.

\section{AIM}

The aim of our study was to check the attitude of students of Lublin universities to vaccination in the COVID-19 period.

\section{MATERIAL AND METHODS}

In December 2020, we conducted a survey to check the attitude of students of Lublin universities to vaccination. The survey was voluntary and anonymous. A total of 75 students participated in the study. They were students of the Medical University of Lublin (MUL), University of Life Sciences in Lublin (ULS), Maria Sklodowska-Curie University in Lublin (UMCS) and Lublin University of Technology (LUT). The students were aged 19-25 and one person was aged 35. The survey consisted of 12 questions (Tab. 1.). It was uploaded and shared on the Google online survey platform.
TABLE 1. The questions asked in the survey.

\begin{tabular}{|c|c|c|}
\hline & Question & Possible answers \\
\hline 1. & Age & Students filled in an empty gap \\
\hline 2. & Sex & Male; female \\
\hline 3. & University & MUL;ULS; UMCS; LUT \\
\hline 4. & $\begin{array}{l}\text { Were you for compulsory } \\
\text { vaccinations before } \\
\text { the COVID-19 pandemic? }\end{array}$ & Yes; no; I don’t know \\
\hline 5. & Do you get vaccinated against flu? & $\begin{array}{l}\text { Yes, every year; } \\
\text { Every few years } \\
\text { No }\end{array}$ \\
\hline 6. & $\begin{array}{l}\text { Did you change your attitude to } \\
\text { vaccination during the COVID-19 } \\
\text { pandemic? }\end{array}$ & Yes; no \\
\hline 7. & $\begin{array}{c}\text { Are you planning to get vaccinated } \\
\text { against COVID-19? }\end{array}$ & Yes; no; I don’t know \\
\hline 8. & Do you know what are AVRs? & Yes; no; I don’t know \\
\hline 9. & $\begin{array}{l}\text { Where do you get information } \\
\text { about vaccinations? }\end{array}$ & $\begin{array}{c}\text { From the medical personnel } \\
\text { From the university } \\
\text { From the Internet } \\
\text { From TV } \\
\text { From my family } \\
\text { From flyers and billboards } \\
\text { From scientific articles } \\
\text { From scientific research } \\
\text { From documentaries } \\
\text { other }\end{array}$ \\
\hline 10. & $\begin{array}{l}\text { What do you think about anti } \\
\text { COVID-19 vaccine? }\end{array}$ & $\begin{array}{l}\text { It is necessary } \\
\text { It is unnecessary } \\
\text { I don't know }\end{array}$ \\
\hline 11. & $\begin{array}{l}\text { If all vaccinations were free would } \\
\text { you apply to get them? }\end{array}$ & Yes; no; I don’t know \\
\hline 12. & $\begin{array}{l}\text { How do you assess the knowledge } \\
\text { of Polish citizens about anti } \\
\text { COVID-19 vaccination? }\end{array}$ & $\begin{array}{c}\text { People have too little information } \\
\text { People have enough information } \\
\text { I have no opinion }\end{array}$ \\
\hline
\end{tabular}

In order to evaluate statistically the collected data, the Statistica v.13.0 software (StatSoft)(Statsoft Sp.zo.o.,Cracow, Poland) was used; $p<0.05$ was considered statistical significance.

\section{RESULTS}

A total of 75 students filled in the questionnaire. There were 56 women and 19 men. Out of them $30(40 \%)$ were from MUL, 15 (20\%) from ULS, 21 from UMCS (28\%) and 9 from LUT $(12 \%)$. Their mean age was 22 years $\pm 1.1(\mathrm{SD})$.

More than half of the respondents were not interested in compulsory vaccinations before the COVID-19 pandemic. Only about $35 \%$ of people expressed a positive opinion about them (Tab. 2.) and they were MUL students (18 persons). However, $80 \%$ of respondents answered that the anti COVID-19 vaccine is necessary. And $81 \%$ answered that Poles have not enough knowledge about the vaccine.

A question was asked about the optional but recommended flu vaccinations. Despite many campaigns encouraging to participate in these vaccinations, only about $7 \%$ get vaccinated every year, and $32 \%$ every few years. The rest of the people do not get the flu vaccine at all. As much as $48 \%$ of respondents knew what the AVRs were.

Due to the current COVID-19 pandemic, we also asked whether respondents changed their minds about vaccines during this period. Only $20 \%$ of respondents, or 15 people, changed their minds about vaccination in the last year. However, more than half of these people altered their thinking to negative about vaccination. Surprisingly, out of 15 people, only 7 changed their minds to positive. 
The majority of respondents admitted to obtaining information about vaccinations from the Internet (Fig. 1).

TABLE 2. Answers given by the students in the survey $(n=75)$.

\begin{tabular}{|c|c|c|c|}
\hline Question & Yes & No & $\begin{array}{c}\text { I don't } \\
\text { know }\end{array}$ \\
\hline $\begin{array}{l}\text { 4. Were you for compul- } \\
\text { sory vaccinations before the } \\
\text { COVID- } 19 \text { pandemic? }\end{array}$ & $26(34.7 \%)$ & $43(57.3 \%)$ & $6(8 \%)$ \\
\hline $\begin{array}{l}\text { 6. Did you change your at- } \\
\text { titude to vaccination during the } \\
\text { COVID-19 pandemic? }\end{array}$ & $15(20 \%)$ & $60(80 \%)$ & N/A \\
\hline $\begin{array}{l}\text { 7. Are you planning to get vac- } \\
\text { cinated against COVID-19? }\end{array}$ & $18(24 \%)$ & $32(42.7 \%)$ & $25(33.3 \%)$ \\
\hline 8. Do you know what are AVRs? & $48(64 \%)$ & $4(5.3 \%)$ & $23(30.7 \%)$ \\
\hline $\begin{array}{l}\text { 11. If all vaccinations were free } \\
\text { would you apply to get them? }\end{array}$ & $36(48 \%)$ & $21(28 \%)$ & $18(24 \%)$ \\
\hline $\begin{array}{l}\text { 5. Do you get vaccinated } \\
\text { against flu? }\end{array}$ & $\begin{array}{l}\text { Yes every } \\
\text { year } \\
5(6.7 \%)\end{array}$ & $\begin{array}{c}\text { No } \\
46(61.3 \%)\end{array}$ & $\begin{array}{l}\text { Every few } \\
\text { years } \\
24(33 \%)\end{array}$ \\
\hline $\begin{array}{l}\text { 10. What do you think about } \\
\text { anti COVID-19 vaccine? }\end{array}$ & $\begin{array}{c}\text { It is } \\
\text { necessary } \\
60(80 \%)\end{array}$ & $\begin{array}{c}\text { It is } \\
\text { unnecessary } \\
6(8 \%)\end{array}$ & $\begin{array}{l}\text { I don't } \\
\text { know } \\
9(12 \%)\end{array}$ \\
\hline $\begin{array}{l}\text { 12. How do you assess the } \\
\text { knowledge of Polish citizens } \\
\text { about anti COVID-19 } \\
\text { vaccination? }\end{array}$ & $\begin{array}{l}\text { People have } \\
\text { too little } \\
\text { information } \\
61(81.3 \%)\end{array}$ & $\begin{array}{l}\text { People have } \\
\text { enough } \\
\text { information } \\
9(12 \%)\end{array}$ & $\begin{array}{l}\text { I have no } \\
\text { opinion } \\
5(3.7)\end{array}$ \\
\hline
\end{tabular}

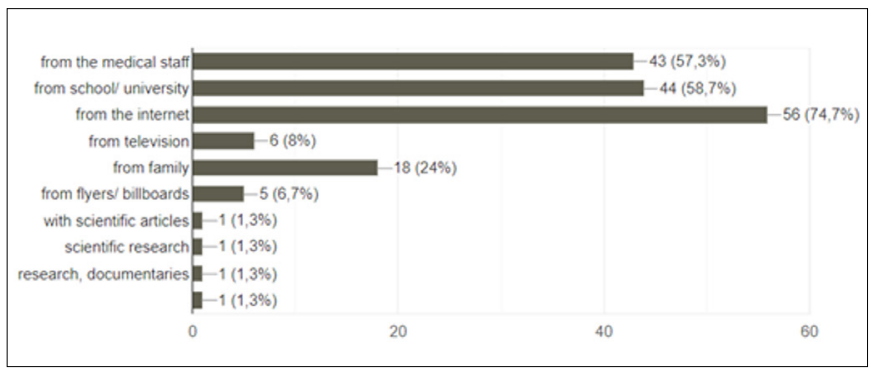

FIGURE 1. Sources of information about vaccinations.

\section{DISCUSSION}

Vaccines are one of the most successful medical advances in modern times. Most vaccine-preventable illnesses are unfamiliar to modern parents. Because of this, people are increasingly questioning the necessity of immunizing, especially because no vaccine is completely free of adverse effects or the risk of complications.

The percentage of respondents willing to get vaccinated against COVID-19 was only $24 \%$, although $80 \%$ of them thought that the anti COVID-19 immunization was necessary. Interestingly, how young people neglect the risk of acquiring the infection. The herd immunity is a benefit but to reach it as much as $80-90 \%$ of the population needs to get immunized [11]. The most common reasons given by unvaccinated people are: too high price and financial problems, frequent mutations of the influenza virus, which, in their opinion, make vaccines useless, fear of vaccination, no disease and "relatively high immunity" of respondents, no examples in the family, considering influenza vaccines ineffective $[12,13]$.

The key issue is the knowledge of AVRs, which is why we also covered this topic in the survey. As many as $64 \%$ of respondents believed that they knew a lot about it, and about $31 \%$ did not know enough. A very positive observation is that only 4 people said they knew nothing about it.
The conducted survey showed a large diversity in relation to vaccinating among students of Lublin universities. Despite the fact that over half of the respondents were against compulsory vaccinations, almost all agreed that vaccinations against COVID-19 are needed. Lublin youth also does not pay attention to the annual flu vaccinations, which may be due to their low knowledge about vaccinations. The respondents themselves believed that knowledge on this subject in Poland was too low. Many people cannot afford to purchase flu vaccines each year. A large proportion of people could change their behavior if vaccinations were reimbursed by the National Health Fund.

It is worth emphasizing that the respondents were young people taking already advantage of the compulsory vaccinations in Poland within the Protective Vaccination Program. It is implemented in Poland for over half age and is essential for maintenance of the epidemiological situation in the country. It includes children and adolescents from 0 to 19 years of age. The effect of the mandatory applied vaccination is to significantly reduce or eliminate diseases such as: diphtheria, tetanus, polio, measles, rubella, hepatitis B or caused by Hemophilus influenzae. Our country can be proud of many positive effects of immunizing children. For polio vaccination, a significant change was introduced to the vaccination calendar in 2016. There was a replacement of the last dose of OPV vaccine with IPV vaccine. This change was done due to WHO recommendation in relation to eradication of wild type 2 polio virus. Another introduction was in 2017: the compulsory vaccination against pneumococci to induce both individual and herd resistance. However, to reach the effect of group immunity these vaccinations should be continued for several years. In case of whooping cough, the epidemiological situation is more complex: after reaching a significant level decline in incidence and mortality from this disease, from the second in the mid-nineties, the incidence increased to about 20003000 cases per year. The trend has continued over the last 10 years. There was an increase in whooping cough incidence. In 2016, a record number of as many as 6,828 cases of whooping cough was reported. The incidence was 17.77 per 100,000 population, which, in comparison with 2015 (4956 cases were registered, the incidence was 12.89), represents an increase by $38 \%$. The increase in whooping cough cases in 2016 (peak epidemic), and numerous cases in 2017 (3067 cases, incidence 7.98 per 100,000 population) indicates an established bacterial circulation in the population while maintaining a high susceptibility of the population to the infection.

It should be emphasized that the implementation of vaccinations against diphtheria, tetanus, whooping cough, polio, measles persisted for most of the years at high level, i.e. between $95 \%$ and $100 \%$. It should be added that, based on preliminary data for 2017, workmanship vaccinations at the level of voivodships varied and was not lower than $90 \%$. It ranged from $93.6 \%$ to $99.6 \%$, except for vaccination against tuberculosis in this case it ranged from $89.6 \%$ to $94.0 \%$. Persisting condition of vaccination of the population $>90.0 \%$ subject to compulsory vaccinations is sufficient to achieve herd immunity to prevent epidemic the spread of disease [14]. Hepatitis B (hepatitis B) in Poland in the 1980s was one of the diseases whose incidence was much higher than the average in other countries in Europe. An improvement program began in the mid-1980s. The sterilization in hospitals was followed by the gradual introduction of vaccinations. Initially, the anti- hepatitis B 
vaccines were given to selected groups only: healthcare professionals, people chronically ill and prepared for surgery. However, the decrease in incidence of the disease was achieved only after introducing in 1994-1996 the program of routine immunization of newborns, for less than 5 cases per 100,000 people in the years 20004 . At that point the value was comparable to the incidence in other European Union countries [15]. A constant decrease in the number of acute cases (from 0.34 per 100 thousand in 2010 to 0.14 per 100 thousand inhabitants in 2017) was observed in the years 2010-2017. In the same period, the number of new diagnoses of chronic HBV infection per 100,000 residents, despite periodic fluctuations, remained at a comparable level and in 2017 was 8.8 [16].

The above examples show that introducing new vaccines to the Protective Vaccination Program in Poland significantly reduced the numbers of new infections in our country and saved many lives. Although there are some anti-vaccine movements, the society as a whole must be educated about the positive effects of immunization and what should be done in case of side effects.

Side effects after vaccination (AVRs) are subject to mandatory reporting and registration for more than 20 years (notification and registration system in operation since 1996). It is a key tool for safety assessment of vaccinations in our country. From the beginning of registration to 2017 , there was an increase in the number of AVRs. This fact should be interpreted by the observed constant increase in sensitivity surveillance system, not an increase in vaccine reactivity. Moreover, it must be taken into account that there was a several-fold increase in the number of vaccine preparations available on the market. In 2016, physicians recognized and reported a total of 2,341 AVRs, including 2,231 mild cases, 107 moderate and 3 severe. The analysis of AVRs reported in Poland is always performed by employees of the Epidemiology Department Diseases of Infection and Supervision (NIZP-PZH) and published once a year in the Bulletin "Vaccinations". The importance of monitoring for adverse reactions of vaccination is multi-faceted as on one hand it aims at detection of new, unusual and rare reactions, monitoring already known reactions, and on the other hand, the determination of risk factors the occurrence of particular types of reactions, identification of the vaccine batch related to the increased percentage of reactions, or safety control of newly introduced vaccines. So it is one of the most important tools for control of post-approval vaccination safety [14].

\section{CONCLUSION}

Students of MUL were the most enthusiastic about mandatory vaccinations and anti COVID-19 immunization. Poles need more reliable information about vaccine to change their attitude towards it.

\section{REFERENCES}

1. D'Amelio E, Salemi S, D'Amelio R. Anti-Infectious Human Vaccination in Historical Perspective. Int Rev Immunol. 2016;35(3):260-90.

2. Talaga K, Bulanda M. Odo Bujwid - an eminent Polish bacteriologist and professor at the Jagiellonian University. Folia Med Cracov. 2014;54(4):1520.

3. Rumik A, Paradowska-Stankiewicz I, Rudowska J, Wiktor A. Pertussis in Poland in 2017. Przegl Epidemiol. 2019;73(3):289-95.

4. Słońska Z, Janusik B. Ocena wykonawstwa obowiazkowych szczepień ochronnych w Polsce w 1986 r. Przegl Epidemiol. 1988;42(2):147-53.

5. Borkowski L, Drąg M, Fal AM, et al. Nauka przeciw pandemii. Szczepienie przeciw COVID-19. Innowacyjne technologie i efektywność. Warszawa, 21 grudnia 2020. [www.naukaprzeciwpandemii.pl]

6. Spencer JP, Pawlowski RHT, Thomas S. Vaccine dverse Events: Separating myth from reality. Am Fam Physician. 2017;95(12):786-94.

7. Kimmel SR. Vaccine adverse events: separating myth from reality. Am Fam Physician. 2002;66(11):2113-20.

8. Tosun S, Olut AI, Tansug N. Adverse effects of single-component measles vaccine in school children. Vaccine. 2017;35(52):7309-11.

9. Fridman D, Monti A, Bonnet MC, et al. Safety of a second dose of varicella vaccine administered at 4 to 6 years of age in healthy children in Argentina. Hum Vaccin. 2011;7(10):1066-71.

10. Regulation of the Minister of Health of December 21, 2010 on adverse vaccination reactions and the criteria for their diagnosis.

11. Smith DR. Herd Immunity. Vet Clin North Am Food Anim Pract. 2019;35(3):593-604.

12. Darden PM, Thompson DM, Roberts JR, et al. Reasons for not vaccinating adolescents: National Immunization Survey of Teens, 2008-2010. Pediatrics. 2013;131(4):645-51.

13. Kajetanowicz A, Kajetanowicz A. Why parents refuse immunization? Wiad Lek. 2016;69(3 Pt 1):346-51.

14. Wojtyniak B, Goryński P. Sytuacja zdrowotna ludności Polski i jej uwarunkowania. Warszawa: Narodowy Instytut Zdrowia Publicznego Państwowy Zakład Higieny; 2018.

15. Magdzik WW. Hepatitis B epidemiology in Poland, Central and Eastern Europe and the newly independent states. Vaccine. 2000;18 Suppl 1:S13-6.

16. Stępień M, Zakrzewska K, Rosińska M. Significant proportion of acute hepatitis B in Poland in 2010-2014 attributed to hospital transmission: combining surveillance and public registries data. BMC Infect Dis. 2018;18(1):164.

\section{Corresponding author}

Dr hab. Barbara Nieradko-Iwanicka, prof. UM

Chair and Department of Hygiene, Medical University of Lublin

11 Radziwillowska St., 20-080 Lublin

E-mail: barbara.nieradko-iwanicka@umlub.pl 